\title{
ECONOMICAL EVALUATION OF REDUCED INTENSITY TILLAGE SYSTEMS, STRAW AND GREEN MANURE COMBINATIONS
}

Vaida STEPONAVIČIENĖ, Institute of Agroecosystems and Soil Sciences, Faculty of Agronomy, Vytautas Magnus University, Address: Studentu str. 11, LT-53361 Akademija, Kauno r., Lithuania; vaida.steponaviciene@vdu.lt (corresponding author) Vaclovas BOGUŽAS, Institute of Agroecosystems and Soil Sciences, Faculty of Agronomy, Vytautas Magnus University, Address: Studentų str. 11, LT-53361 Akademija, Kauno r., Lithuania; vaclovas.boguzas@ vdu.lt Asta BENDORAITYTE், Institute of Economics, Accounting and Finance, Faculty of Bioeconomy Development, Vytautas Magnus University, Address: Studentų str. 11, LT-53361 Akademija, Kauno r., Lithuania; asta.bendoraityte@ vdu.lt Aušra SINKEVIČIENE், Institute of Agroecosystems and Soil Sciences, Faculty of Agronomy, Vytautas Magnus University, Address: Studentų str. 11, LT-53361 Akademija, Kauno r., Lithuania; ausra.sinkeviciene@ vdu.lt

Lina SKINULIENE், Institute of Agroecosystems and Soil Sciences, Faculty of Agronomy, Vytautas Magnus University, Address: Studentų str. 11, LT-53361 Akademija, Kauno r., Lithuania; lina.skinuliene@ vdu.lt

Since 1999, a long-term field experiment has been done at the Experimental Station of Vytautas Magnus University (former Aleksandras Stulginskis University) at $54^{\circ} 52^{\prime} 50 \mathrm{~N}$ latitude and $23^{\circ} 49^{\prime} 41 \mathrm{E}$ longitude. The soil of the experiment site is Epieutric Endocalcaric Endogleyic Planosol (Endoclayic, Aric, Drainic, Humic, Episiltic) according to WRB (2014). The objective of our investigations was to assess the long-term impact of reduced intensity tillage systems, straw and green manure combinations on productivity and economical evaluation.

In a coherent farming system, soil tillage should be reduced by minimizing mechanical tillage and maximizing the use of biological soil fertility maintenance measures combined with a soil quality improvement system. Long-term use of plant residues and green manure in combination with a complex application of reduced soil tillage and direct drilling has a positive impact on the sus tainability of agroecosystems and help maintain crop rotation productivity. Performed analysis allows expecting the positive cash flows in catch cropping for green manure and rotovating (GMR) and no-tillage (NT) tillage systems more often comparing with other more intensive tillage systems. These systems ensure more stable yields and positive cash flows, because of lower operation cost of machinery notillage (NT).

Keywords: long-term, tillage systems, productivity, economical evaluation

\section{INTRODUCTION}

Soil tillage has long-term impacts on the agroecosystems. Understanding the structure and functions of the soil ecosystem, when applying soil tillage systems of different intensity or direct drilling is an essential condition for any future farming system. Reduced intensity tillage systems have been proposed as an alternative that may provide many of the soil conservation benefits while maintaining the productivity and economic returns of the crops (Archer, Reicosky, 2014). Increase of crop yields and savings of specific input costs, i.e., labour, fuels, equipment, fertilizer and pesticide are considered as the key factors while evaluating the efficiency of reduced tillage systems (Kovacevet al., 2011, Huang et al., 2013). However, there are a few controversial views on tillage effects on net economic results. One studies showed no economic benefit of using conservation tillage systems (Popp et al., 2001) arguing that higher financial costs from deeper tillage can be compensated by higher yields and generate the hihger net returns. As opposite, in the other studies possitive economical effets of redused tillage systems compared to conventional tillage are observed (Ozpinar, 2006; Su, 2007, Jug et al, 2007; Vach et. al, 2016,). Reduced intensity tillage systems are reported to ensure the reduction of production cost (Aryal 2015) and no or minimul penalty on yields (Sijtsmaa, 1998), or even increasing crop yield (Vach et al., 2015).

Tillage intensity affects not only physical properties of the soil but also carbon stocks in it. A number of researchers have reported that regular deep tillage negatively affects many soil properties, it promotes the formation of a plough pan between the topsoil and subsoil, reduces humus content, which in turn results in lower crop yields (Maikštennienè, 2000). An analysis of the scientific literature has led to the conclusion that the sustainability of the agroecosystems could be enhanced through the improvement of organic fertilization of plants. To achieve this under Lithuania's climate conditions, it is necessary to optimize the use of plant residues.

Climate change affects agroecosystems, which undergo significant qualitative and quantitative changes in the vegetation, microorganisms and soil. Climate change results in the intensified soil degradation and disturbance

Copyright $\odot 2019$ The Authors. Published by Vytautas Magnus University. This is an open-access article distributed under the terms of the Creative Commons Attribution License (CC BY 4.0), which permits unrestricted use, distribution, and reproduction in any medium, provided the original author and source are credited. 
of plant nutrition and development (Cornic, 1994; Kirnak et al., 2001; Šliogerytė et al., 2009). Therefore, researchers worldwide have focused their attention on the interaction among the components of the agroecosystem, feasibility of their control in the context of changing environmental conditions. The adverse effects of the meteorological conditions on plants are more often observed. The changes in the meteorological conditions are directly related to human activities. The different scenarios of climate change suggest that temperature rise and changing soil moisture will be the main factors reducing the crop productivity in the future. With the global climate change, increasing frequency and severity of drought events are being forecasted (Dai, 2013; Prudhomme et al., 2014; Trenberth et al., 2014). Seeking to eliminate short term effects and year-to-year variability of crop yields and crop prices and to evaluate the effects of tillage systems on the ecosystem below and above the soil surface the long-term studies are used (Karlen et al., 2013). Long-term studies are useful for demonstrating the cumulative effects of soil tillage strategies on crop yield and can provide a better understanding of the change of soil properties and effectys of soil management (Stanger et al., 2008). The aim set out to evaluate the impacts of long-term tillage of different intensities in combination with the use of plant residues and green manure on the sustainability of agroecosystems and economical evaluation.

\section{RESEARCH AND METHODS}

Research was carried out during the period of 2000-2017 in a long-term field experiment, set up in 1999, at the Experimental Station of Vytautas Magnus University. The soil in the experimental site was Epieutric Endocalcaric Endogleyic Planosol (Endoclayic, Aric, Drainic, Humic, Episiltic) according to the WRB 2014 classification. The longterm experiment was laid out in a split-plot design with 4 replications and a total of 48 plots. The initial plot size was 102 $\mathrm{m}^{2}(6 \mathrm{~m} \times 17 \mathrm{~m})$ and the harvested plot size was $30 \mathrm{~m}^{2}(15 \mathrm{~m} \times 2.0 \mathrm{~m})$.

Agroecosystems of a spring rape (Brassica napus L.), a winter wheat (Triticum aestivum L.), and a spring barley (Hordeum vulgare L.) - the most popular crops grown in Lithuania - were chosen as the study objects.

In a two-factor field experiment, a straw (factor A) was removed (R) from one part of the experimental field and on the other part of the field all the straw yield was chopped and spread (S) at harvest. 6 different tillage systems (factor B) were investigated as subplots: conventional ploughing (CP) at the depth of $23-25 \mathrm{~cm}$ in autumn, shallow ploughing (SP) at the depth of 10-12 cm in autumn, shallow loosening (SL) with sweep cultivator and disc harrow at the depth of 8-10 cm in autumn, shallow rotovating (SR) at the depth of 5-6 $\mathrm{cm}$ before the next crop sowing, catch cropping for green manure and rotovating (GMR) at the depth of 5-6 cm before the next crop sowing, and no-tillage (NT) - direct drilling. White mustard (Sinapis alba L.) was sown as a catch crop for green manure on stubble only in GMR plots right after the harvest of winter wheat and spring barley.

The crops were sown with a pneumatic direct drilling machine Väderstad Rapid 300C Super XL (Sweden). After harvesting, the plots of conventional ploughing and shallow ploughing treatments were stubble-cultivated with a plough. The plots of conventional ploughing treatment were ploughed deeply in the autumn, while the plots of shallow ploughing treatment were shallow-cultivated with a cultivator with coulters and disks at the depth of 8$10 \mathrm{~cm}$. The plots of shallow ploughing and green manure and rotovating treatments were only tilled with a rotovator Väderstad Carrier 300 (Sweden) before the sowing. After harvesting the cereals, the plots of green manure and rotovating treatment were sown with a catch crop - white mustard - for green manure. The plots of no-tillage were neither tilled in autumn non in spring.

The plots of cereals and oilseed rape were combine-harvested the grain yield was weighed. The grain yield of cereals was adjusted to $14 \%$ moisture and that of oilseed rape to $8.5 \%$ moisture, $100 \%$ purity of grain mass. Grain purity was determined on a $2 \mathrm{~kg}$ composite grain sample composed of grain from all replications of each treatment. The grain was put into cloth bags. Three samples from the composite sample of each treatment were weighed. Admixtures and impurities were removed from them and clean grain was weighed.

The data were processed using a two-factor ANOVA from the software package SYSTAT 10 (SPSS Inc., 2000; Leonavičienè, 2007). The significance of differences among all treatments was estimated by the LSD test.

For the economic evaluation of the six tillage systems compared (CP, SP, SL, SR, GMR, NT), the incremental cash flows for each system were calculated. The incremental net cash flows were determined as the additional increase or decrease in revenue and total cost of machinery arising of the use of different tillage system (formula 1).

$$
\text { Net cash } \text { flow }_{t, n}=\Delta \text { Revenue }_{t, n}-\Delta \text { Cost of machinery } y_{t, n}
$$

$\begin{array}{ll}\text { Where: } & \mathrm{t} \text { - period of time } \\ \mathrm{n} \text { - tillage system. }\end{array}$

The incremental net cash flow shows the difference between the change in revenues and machinery cost, while other crop growing conditions remained constant. To evaluate the possible revenues, the crop yield data, collected during the experiment were used (Table 1). The amount of net change was analysed under two methods: applying different soil tillage systems compared with average productivity that year and the yields observed in traditional tillage system. The change in revenues were calculated by evaluating the quantity of the final crop production $(\mathrm{Y})$ and the production price (P) of each analysed period in Lithuania 
Table 1. Variables of revenues and cost of machinery

\begin{tabular}{|c|c|c|c|c|}
\hline \multicolumn{2}{|r|}{ Variable } & Abbreviation & Description of the variable & Database \\
\hline \multirow{2}{*}{ 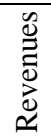 } & Crop yield & $\mathrm{Y}$ & Yield per hectare $\left(\mathrm{t} \mathrm{ha}^{-1}\right)$ & $\begin{array}{c}\text { Field } \\
\text { experiment }\end{array}$ \\
\hline & Price of the crops & $\mathrm{P}$ & Price per tonne $($ Eur/t) & Eurostat \\
\hline \multirow{6}{*}{ 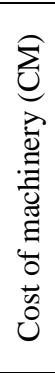 } & Labour cost & $\mathrm{L}$ & Cost of labour force per hectare (Eur/ha) & \multirow{6}{*}{$\begin{array}{l}\text { Mechanized } \\
\text { Agriculture, } \\
\text { 2005-2017 }\end{array}$} \\
\hline & Fuels and oils & $\mathrm{F}$ & Cost of fuels and oils per hectare (Eur/ha) & \\
\hline & $\begin{array}{l}\text { Depreciation of the } \\
\text { machinery }\end{array}$ & Dep & Cost of depreciation of the machinery per hectare (Eur/ha) & \\
\hline & $\begin{array}{l}\text { Repairing and } \\
\text { technical servicing } \\
\text { of machinery }\end{array}$ & $\mathrm{R}$ & $\begin{array}{l}\text { Cost of repairing and technical servicing of machinery per } \\
\text { hectare (Eur/ha) }\end{array}$ & \\
\hline & Other cost & $\mathrm{O}$ & $\begin{array}{l}\text { Cost of other cost (management and administration cost) } \\
\text { per hectare (Eur/ha) }\end{array}$ & \\
\hline & Profit marge & $\mathrm{PM}$ & Cost of profit marge per hectare (Eur/ha) & \\
\hline
\end{tabular}

The operating cost of machinery were analysed as the change of inputs of production. Seeking to evaluate the total costs (CM) of tillage under analysed tillage systems, sum of separate inputs cost (L, F, Dep., R, O and PM) were analysed. Total cost of machinery $(\mathrm{CM})$ is provided in the table 1 .

Table 2. The Yields and cost of machinery of different tillage systems in the selected period

\begin{tabular}{|c|c|c|c|c|c|c|c|c|c|c|c|c|c|}
\hline \multirow{3}{*}{ Year } & \multirow{3}{*}{ Crop } & \multicolumn{12}{|c|}{ Tillage systems } \\
\hline & & \multicolumn{2}{|c|}{$\mathbf{C P}$} & \multicolumn{2}{|c|}{ SP } & \multicolumn{2}{|c|}{ SL } & \multicolumn{2}{|c|}{ SR } & \multicolumn{2}{|c|}{ GMR } & \multicolumn{2}{|c|}{ NT } \\
\hline & & $\begin{array}{l}\mathrm{Y}, \\
\mathrm{t} / \mathrm{ha}\end{array}$ & $\begin{array}{l}\text { CM, } \\
\text { Eur/ha }\end{array}$ & $\begin{array}{l}Y, \\
\text { t/ha }\end{array}$ & $\begin{array}{l}\text { CM, } \\
\text { Eur/ha }\end{array}$ & $\begin{array}{l}Y, \\
\text { t/ha }\end{array}$ & $\begin{array}{l}\text { CM, } \\
\text { Eur/ha }\end{array}$ & $\begin{array}{l}\mathrm{Y}, \\
\mathrm{t} / \mathrm{ha}\end{array}$ & $\begin{array}{l}\text { CM, } \\
\text { Eur/ha }\end{array}$ & $\begin{array}{l}Y, \\
\text { t/ha }\end{array}$ & $\begin{array}{l}\text { CM, } \\
\text { Eur/ha }\end{array}$ & $\begin{array}{l}\text { Y, } \\
\text { t/ha }\end{array}$ & $\begin{array}{l}\text { CM, } \\
\text { Eur/ha }\end{array}$ \\
\hline 2005 & Winter wheat & 9.7 & 40.3 & 9.1 & 34.2 & 9.6 & 19.7 & 10.9 & 25.8 & 10.9 & 25.8 & 10.4 & 0.0 \\
\hline 2006 & Spring barley & 3.6 & 41.7 & 3.2 & 35.4 & 3.7 & 20.6 & 3.2 & 26.1 & 3.6 & 26.1 & 3.4 & 0.0 \\
\hline 2007 & Spring rape & 2.1 & 42.3 & 2.2 & 35.9 & 2.1 & 39.1 & 2.1 & 26.1 & 1.8 & 26.1 & 2.1 & 0.0 \\
\hline 2008 & Winter wheat & 7.2 & 55.0 & 6.7 & 46.8 & 7.1 & 36.8 & 7.9 & 24.9 & 7.3 & 24.9 & 7.8 & 0.0 \\
\hline 2009 & Spring barley & 5.4 & 53.6 & 5.1 & 45.5 & 5.2 & 31.9 & 4.5 & 22.0 & 4.6 & 22.0 & 4.5 & 0.0 \\
\hline 2010 & Spring rape & 1.7 & 60.8 & 1.6 & 51.7 & 1.5 & 23.5 & 1.5 & 28.4 & 1.3 & 28.4 & 1.5 & 0.0 \\
\hline 2011 & Winter wheat & 5.7 & 55.6 & 5.2 & 47.3 & 5.3 & 23.5 & 6.5 & 29.0 & 6.6 & 29.0 & 6.4 & 0.0 \\
\hline 2012 & Spring barley & 5.1 & 57.6 & 4.4 & 49.0 & 4.3 & 24.3 & 4.5 & 29.8 & 4.5 & 29.8 & 4.6 & 0.0 \\
\hline 2013 & Spring rape & 0.6 & 59.4 & 0.6 & 50.5 & 0.6 & 24.9 & 0.3 & 30.7 & 0.6 & 30.7 & 0.6 & 0.0 \\
\hline 2014 & Winter wheat & 8.0 & 59.1 & 7.8 & 50.2 & 7.8 & 24.6 & 8.0 & 29.3 & 8.8 & 29.3 & 8.3 & 0.0 \\
\hline 2015 & Spring barley & 7.3 & 58.4 & 6.7 & 49.6 & 7.2 & 25.0 & 7.4 & 31.1 & 7.4 & 31.1 & 7.5 & 0.0 \\
\hline 2016 & Spring rape & 1.1 & 55.5 & 1.2 & 47.2 & 1.2 & 25.1 & 1.2 & 30.8 & 1.3 & 30.8 & 1.2 & 0.0 \\
\hline 2017 & Winter wheat & 9.0 & 113.9 & 8.9 & 96.8 & 9.3 & 25.4 & 10.8 & 31.5 & 10.3 & 31.5 & 9.8 & 0.0 \\
\hline
\end{tabular}

The same method (comparison with average cost of tillage and cost of traditional tillage system). The cost included fixed and variable costs and the difference between all tillage systems were analysed. The biggest differences in tillage cost among tillage systems consist mainly because of differences in the capital cost of tractors and tillage equipment, labour cost and fuels comparing systems with NT. Table 2 variables of revenues and cost of machinery

\section{RESEARCH RESULTS}

Sustainable agroecosystems are able to maintain their condition, productivity and biodiversity, as well as their integrity over time and in the context of human activity and use. The sustainability of agroecosystems is inseparable from the stability of their productivity. In order to illustrate this, we estimated crop productivity differences $\%$ from the year 2000 to 2017. In terms of crop productivity, all the tested long-term complex measures of different intensities were similar, both when comparing with average productivity that year and when estimating cumulative differences com-pared with deep ploughing.

Long-term and regular spreading of plant residues and the use of white mustard grown in the stubble for green manure increased winter wheat productivity; however, these and other tested complex measures did not have significant effect on spring barley productivity. Long-term application of less intensive soil tillage in combination with the use of plant residues and green manure allows maintaining stability of productivity of agroecosystems. 


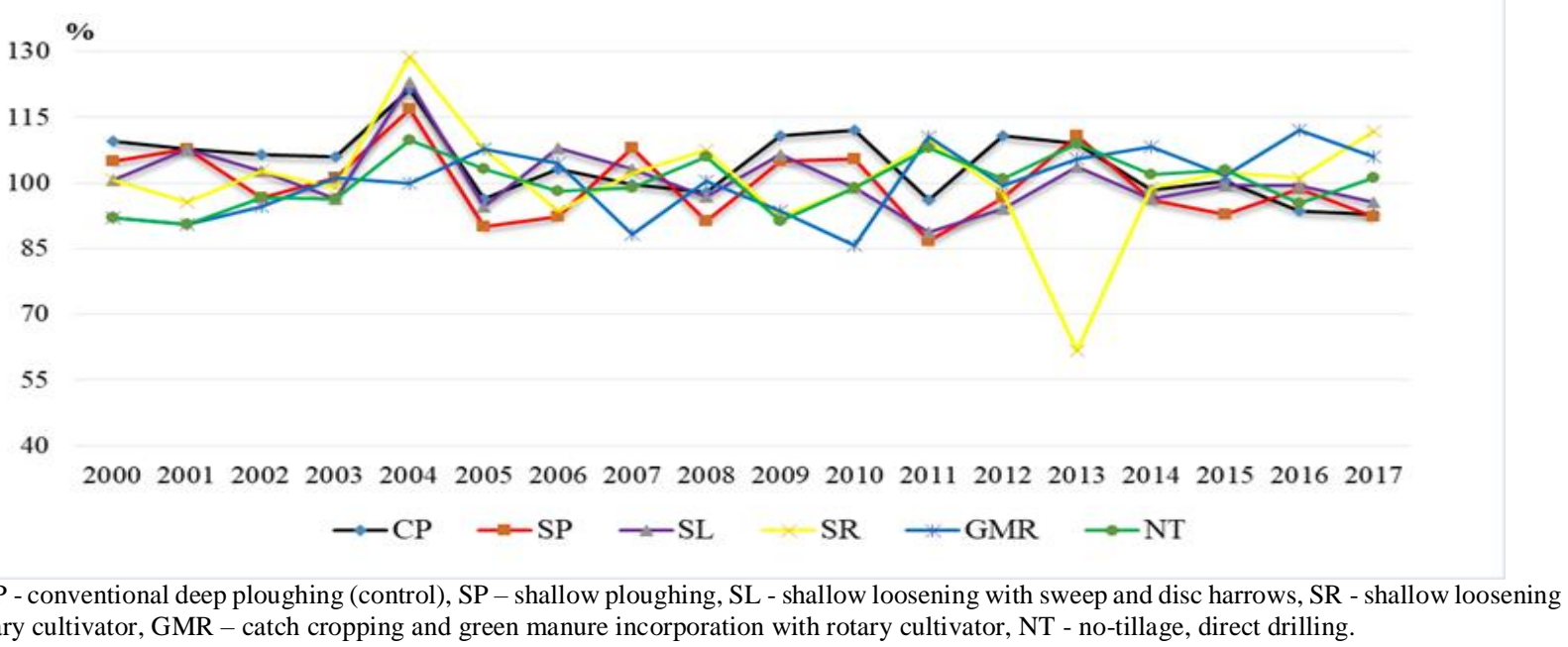

Notes CP - conventional deep ploughing (control), SP - shallow ploughing, SL - shallow loosening with sweep and disc harrows, SR -
with rotary cultivator, GMR - catch cropping and green manure incorporation with rotary cultivator, NT - no-tillage, direct drilling.

Figure 1. Crop productivity differences $\%$ as influenced by long-term complex measures of different intensities compared with average productivity that year, 2000-2017.

Six tillage systems compared in this study showed different net cash flows results in both cases, when analysis is done comparing with average productivity and machinery cost in particular periods (Table 2), and in the case there, assessment is done comparing each systems results with deep ploughing (control) (Table 3). Comparing net cash flows with average productivity in particular year, the most intensive tillage systems (CP, SP) were characterize by lowest net cash flows. On one hand, it was determined by higher machinery cost, but on the other hand, the yield of crops was relative lower comparing with other tillage systems. However, conventional deep ploughing system generated the highest cash flows (the cases of spring rape in 2010 and spring barley in 2012). Analysing less intensive tillage systems it is noticeable that NT system nor only generated positive cash flows, but also most frequently in comparison with other tillage systems generated the highest cash flows. In most periods, the GMR also generated positive cash flows, which allows assessing the positive tillage effect on crop yield, comparing with SR tillage system.

Table 3. Net cash flows differences $(€)$ applying different intensity soil tillage systems compared with average productivity that year, 2005-2017.

\begin{tabular}{|l|l|c|c|c|c|c|c|}
\hline Year & \multicolumn{1}{|c|}{ Crop } & CP & SP & SL & SR & GMR & NT \\
& & & & & & & \\
\hline $\mathbf{2 0 0 5}$ & Winter wheat & -46.35 & -99.08 & -40.95 & 77.15 & 78.10 & 60.27 \\
\hline $\mathbf{2 0 0 6}$ & Spring barley & -0.23 & -33.27 & 38.97 & -19.64 & 20.72 & 23.42 \\
\hline $\mathbf{2 0 0 7}$ & Spring rape & -9.71 & 41.54 & 11.97 & 19.71 & -56.90 & 27.29 \\
\hline $\mathbf{2 0 0 8}$ & Winter wheat & -42.70 & -110.49 & -35.78 & 100.68 & 16.55 & 109.41 \\
\hline $\mathbf{2 0 0 9}$ & Spring barley & 30.28 & 11.67 & 32.70 & -20.86 & -15.35 & -3.44 \\
\hline $\mathbf{2 0 1 0}$ & Spring rape & 35.26 & 13.00 & 9.86 & 4.94 & -57.82 & 33.32 \\
\hline $\mathbf{2 0 1 1}$ & Winter wheat & -65.82 & -172.89 & -122.29 & 125.71 & 136.01 & 136.12 \\
\hline $\mathbf{2 0 1 2}$ & Spring barley & 79.92 & -41.56 & -38.92 & -10.39 & 1.62 & 47.47 \\
\hline $\mathbf{2 0 1 3}$ & Spring rape & -2.70 & 9.69 & 21.30 & -64.72 & 18.99 & 56.67 \\
\hline $\mathbf{2 0 1 4}$ & Winter wheat & -40.52 & -61.55 & -32.80 & -5.97 & 116.72 & 62.60 \\
\hline $\mathbf{2 0 1 5}$ & Spring barley & -13.85 & -84.01 & 8.05 & 33.54 & 24.93 & 70.38 \\
\hline $\mathbf{2 0 1 6}$ & Spring rape & -48.01 & -10.51 & 11.56 & 9.50 & 56.91 & 18.42 \\
\hline $\mathbf{2 0 1 7}$ & Winter wheat & -159.91 & -153.67 & -29.59 & 205.92 & 119.17 & 77.90 \\
\hline
\end{tabular}

Source: own calculation

Notes CP - conventional deep ploughing (control), SP - shallow ploughing, SL - shallow loosening with sweep and disc harrows, SR - shallow loosening with rotary cultivator, GMR - catch cropping and green manure incorporation with rotary cultivator, NT - no-tillage, direct drilling.

Additionally, economical analysis was carried out for different tillage systems comparing them with deep ploughing (control) system. In this case, NT tillage systems was characterized positive cash flows in growing winter wheat. But the cash flows generated in case of spring barley and spring rape were ambiguous. In most years generated cash flows were positive, but in some periods (in 2009, 2010, 2012) were negative. For growing spring wheat, the most effective tillage systems were either NT, or GMR. Comparing GMR with SR systems, GMR was characterized with higher crop yields and with higher cash flows. However, in most periods, the most intensive tillage system (SP) generated lowest cash flows. This can be explained relative higher operation cost of machinery, but higher cost in this tillage system didn't allowed to generated higher crop yields, comparing to other tillage systems. 
Table 4. Net cash flows differences $(€)$ applying different intensity soil tillage systems compared with deep ploughing (control), 20052017

\begin{tabular}{|c|c|c|c|c|c|c|c|}
\hline Year & Crop & $\mathbf{C P}$ & SP & SL & SR & GMR & NT \\
\hline 2005 & Winter wheat & - & -52.74 & 5.40 & 123.50 & 124.45 & 106.62 \\
\hline 2006 & Spring barley & - & -33.04 & 39.20 & -19.41 & 20.95 & 23.65 \\
\hline 2007 & Spring rape & - & 51.26 & 21.68 & 29.43 & -47.19 & 37.00 \\
\hline 2008 & Winter wheat & - & -67.79 & 6.92 & 143.38 & 59.24 & 152.11 \\
\hline 2009 & Spring barley & - & -18.61 & 2.42 & -51.14 & -45.63 & -33.73 \\
\hline 2010 & Spring rape & - & -22.26 & -25.40 & -30.32 & -93.08 & -1.94 \\
\hline 2011 & Winter wheat & - & -107.07 & -56.48 & 191.53 & 201.83 & 201.94 \\
\hline 2012 & Spring barley & - & -121.48 & -118.85 & -90.31 & -78.30 & -32.46 \\
\hline 2013 & Spring rape & - & 12.39 & 24.00 & -62.02 & 21.70 & 59.37 \\
\hline 2014 & Winter wheat & - & -21.02 & 7.72 & 34.55 & 157.24 & 103.13 \\
\hline 2015 & Spring barley & - & -70.17 & 21.90 & 47.39 & 38.78 & 84.23 \\
\hline 2016 & Spring rape & - & 37.50 & 59.57 & 57.50 & 104.91 & 66.43 \\
\hline 2017 & Winter wheat & - & 6.24 & 130.32 & 365.83 & 279.08 & 237.81 \\
\hline
\end{tabular}

Source: own calculation

Notes CP - conventional deep ploughing (control), SP - shallow ploughing, SL - shallow loosening with sweep and disc harrows, SR - shallow loosening with rotary cultivator, GMR - catch cropping and green manure incorporation with rotary cultivator, NT - no-tillage, direct drilling.

In summary, it can be concluded that in a coherent farming system, soil tillage should be reduced by minimizing mechanical tillage and maximizing the use of biological soil fertility maintenance measures combined with a soil quality improvement system. Long-term use of plant residues and green manure in combination with a complex application of reduced soil tillage and direct drilling has a positive impact on the sustainability of agroecosystems and help maintain crop rotation productivity. Performed analysis allows expecting the positive cash flows in GMR and NT tillage systems more often comparing with other more intensive tillage systems. These systems ensure more stable yields and positive cash flows, because of lower operation cost of machinery (NT).

\section{CONCLUSIONS AND DISCUSSION}

During a 17-year period of the field experiments, the following long-term changes in the agroecosystems stood out:

1. Long-term and regular spreading of plant residues and the use of white mustard grown in the stubble for green manure increased winter wheat productivity; however, these and other tested complex measures did not have significant effect on spring barley productivity. Long-term application of less intensive soil tillage in combination with the use of plant residues and green manure allows maintaining stability of productivity of agroecosystems.

2. Economical evaluation shows positive economic impact of less intensive tillage systems cash flows generated by farms, which remain stable in continuously use of no tillage or catch cropping and green manure incorporation with rotary cultivator tillage systems.

Acknowledgement. This work was supported by the project of The Ministry of Agriculture of the Republic of Lithuania „Investigation and economic-environmental evaluation of the no-till technology complex"

\section{REFERENCES}

1. Archer D.W., ReicoskY D. C. 2014. Economic Performance of Alternative Tillage Systems in the Northern Corn Belt. Agronomy Journal, Vol. 101, No. 2, pp. 296-304. https://doi.org/10.2134/agronj2008.0090x

2. Aryal, J. P., Sapkota T.B., Jat M.L., Bishnoi D.K. 2015. On-farm economic and environmental impact of zero-tillage wheat: a case of north-west India. Experimental Agriculture, Vol. 51, No. 1, pp. 1-16. https://doi.org/10.1017/S001447971400012X

3. Cornic, G. 1994. Drought stress and high light effects on leaf photosynthesis. Photoinhibition of photosynthesis, Vol. 17, pp. 297313.

4. Dai, A. 2013. Increasing drought under global warming in observations and models. Nature Climate Change, Vol. 3, pp. 52-58. https://doi.org/10.1038/nclimate1633

5. Feiza V., Feizienė D., Sinkevičienė A., Bogužas V., Putramentaitė A., Lazauskas S., Deveikytė I., Seibutis V., Steponavičienė V., Pranaitiene S. 2015. Soil water capacity, pore-size distribution and CO 2 e-flux in different soils after long-term no-till management. Zemdirbyste-Agriculture, Vol. 102, No. 1, pp. 3-14. https://doi.org/10.13080/z-a.2015.102.001

6. Huang M., Jiang L., Zou Y., Xu s., Deng G. 2013. Changes in soil microbial properties with no-tillage in Chinese cropping systems. Biology and fertility of soils, Vol. 49, Iss. 4, pp. 37-377. https://doi.org/10.1007/s00374-013-0778-6

7. Jug, D., Miki B.M., Stipeševi B.D., Raspudi E.S., Drezner G., Brozovi B.Ž. 2007. Economic evaluation of winter wheat production in different soil tillage systems. Bulletin of University of Agricultural Sciences and Veterinary Medicine Cluj-Napoca. Horticulture, Vol. 64, No. 1-2, pp. 485-489.

8. Karlen D.L., Cambardella C.A., Kovara J.L., Colvin T.S. 2013. Soil quality response to long-term tillage and crop rotation practices. Soil and Tillage Research, Vol. 133, pp. 54-64. https://doi.org/10.1016/j.still.2013.05.013 
9. Kirnak, H., Kaya C., Tas I., Higgs D. 2001. The influence of water deficit on vegetative growth, physiology, fruit yield and quality in eggplants. Bulgarian Journal of Plant Physiology, Vol. 27, pp. 34-46.

10. Kovacev I., Copec K., Fabianic G., Kosutic S.2011. Economic efficiency of non-conventional soil tillage systems in oil seed rape and winter barley production. Aktualni Zadaci Mehanizacije Poljoprivrede. Zbornik radova, 39. Međunarodnog Simpozija iz Područja Mehanizacije Poljoprivrede, Opatija, Hrvatska, pp. 271-279.

11. Leonavičienè, Teresė. 2007. SPSS programų paketo taikymas statistiniuose tyrimuose. Vilnius: Vilniaus pedagoginio universiteto leidykla, No. 89, pp. 61-67. (In Lithuanian)

12. Maikštènienè, S. 2000. Possibilities of primary tillage reduction on clay loam soil. The Results of Long-term Field Experiments in Baltic States. Proceedings of the International Conference, Jelgava, Latvia, pp. 106-113.

13. Mechanizuotų žemès ūkio paslaugų įkainiai (Rates of mechanized agricultural services) 2018. D. 1, Pagrindinio žemés dirbimo darbai / [parengè: I. Skrebutėnienè, A. Stalgienè]. Vilnius : Lietuvos agrarinès ekonomikos institutas, 54 p. (In Lithuanian)

14. Ozpinar, S., 2006. Effects of tillage systems on weed population and economics for winter wheat production under the Mediterranean dryland conditions. Soil and Tillage Research, Vol. 87, Iss. 1, pp. 1-8. https://doi.org/10.1016/j.still.2005.02.024

15. Popp M.P., Keislingb T.C., Dillonc C.R., Manninga P.M. 2001. Economic and agronomic assessment of deep tillage in soybean production on Mississippi River Valley soils. Agronomy Journal, Vol. 93, pp. $164-169$. https://doi.org/10.2134/agronj2001.931164x

16. Prudhomme C., Giuntoli I., Robinson E.L., Clark D.B., Arnell N.W., Dankers R., Fekete B.M., Franssen W., GertenD., Gosling S.N., Hagemann S., Hannah D.M., Kim H., Msaki Y., Satoh Y., Stacke T., Wada Y., Wisser D. 2014. Hydrological droughts in the 21st century, hotspots and uncertainties from a global multimodel ensemble experiment. Proceedings of the National Academy of Sciences, Vol. 111, Iss. 9, pp. 3262-3267. https://doi.org/10.1073/pnas.1222473110

17. Sua Z., Zhang J., Wua W., Caic D., Guanghui L., Huanga J., Gaob J., Hartmanne R., Gabrielse D. 2007. Effects of conservation tillage practices on winter wheat water-use efficiency and crop yield on the Loess Plateau, China. Agricultural Water Management, Vol. 87, Iss. 3, pp. 307-314. https://doi.org/10.1016/j.agwat.2006.08.005

18. Stanger T.F., Lauerb J.G., Chavasc J.P. 2008. The Profitability and Risk of Long-Term Cropping Systems Featuring Different Rotations and Nitrogen Rates. Agronomy Journal, Vol. 100, Iss. 1, pp. 105-113. https://doi.org/10.2134/agronj2006.0322

19. Šliogerytė K., et al. 2009. Paprastojo kukurūzo (Zea mays L.), auginto skirtingomis drègmès ir temperatūros sąlygomis, fotosintezès ir biometrinių rodiklių kitimas. Sodininkystè ir daržininkystė, Vol. 28, No. 4, pp. 189-197. (in Lithuanian)

20. Trenberth K.E., Dai A., van der Schrier G., Jones P.D., Barichivich J., Briffa K.R., Sheffield J. 2014. Global warming and changes in drought. Nature Climate Change,Vol. 4, Iss. 1, pp. 17-22. https://doi.org/10.1038/nclimate2067

21. Vach, M., Strašil Z., Javůrek M.2016. Economic efficiency of selected crops cultivated under different technology of soil tillage. Scientia agriculturae bohemica, Vol. 47, Iss. 1, pp. 40-60. https://doi.org/10.1515/sab-2016-0007 